\title{
Aspects on the Harmonization of Copyright and Related Rights in the Information Society in the European Union Legislation
}

\author{
Cristina Mihaela Salcă Rotaru \\ University Transivania of Braşov, Faculty of Law, \\ Romania, rotaruc@unitbv.ro
}

\begin{abstract}
The influence of technological development has led to the multiplication and diversification of the creativity, production and exploitation vectors of copyright and related rights legislation, which must be adapted with economic realities and new forms of exploitation. Legislation in this area is comprehensive, addressing different aspects of copyright and related rights protection, across different regulatory levels: international, European and national. Legislative harmonization of copyright and related rights must be based on a high level of protection, should take into account all regulatory levels, for maintaining and developing creativity in the interests of authors, producers, consumers, and culture. However, legislative differences as well as legal uncertainty have become increasingly prominent with the evolution of the information society, which has already led to the intensification of the cross-border exploitation of intellectual property. This paper aims to:

- examine the state of play of current legislation at EU level in the light of the interest of harmonious administration of justice, the elimination of protection differences and possible restrictions on the free movement of services and products incorporating or based on intellectual property,

- to highlight, where appropriate, situations of legislative inconsistency.

The research will take into account the binding EU legislation, the cases brought before the Court of Justice of the European Union and the new recommendations in the field.
\end{abstract}

Keywords: information society, protection of copyright and related rights; legislative inconsistency.

DOI: 10.22618/TP.PCMS.20181.156006

This is an Open Access article distributed in accordance with the Creative Commons Attribution Non Commercial (CC-BY-NC-ND 4.0) license, which permits others to copy or share the article, provided original work is properly cited and that this is not done for commercial purposes. Users may not remix, transform, or build upon the material and may not distribute the modified material (http:/ / creativecommons.org/ licenses/by-nc/4.0/) 


\title{
Aspects on the Harmonization of Copyright and Related Rights in the Information Society in the European Union Legislation
}

\author{
Cristina Mihaela Salcă Rotaru \\ University Transivania of Braşov, Faculty of Law, \\ Romania
}

\section{Complexity of the legislative framework}

On European Union (EU) level, through Directive 29 of 2001 on the harmonization of certain aspects of copyright and related rights in the information society, ${ }^{1}$ three important issues have been achieved: the adaptation of EU copyright law and related rights to technological developments, especially in the information society; the implementation of the WIPO International Treaty on Copyright and the implementation of the WIPO International Treaty on Interpretations and Enforcement and phonograms.

This directive is part of a set of EU normative acts in the field of intellectual property protection and respect, orphan works regulations or collective rights management, in other words, the copyright field.

As EU legislation is in line with international legislation in the field, a brief look at it needs to be done. The first step was taken by the EU through Council resolution of 14 May 1992 on Increased protection for copyright and neighbouring rights ${ }^{2}$, showing that:

Whereas advances in technology have encouraged the exploitation of literary and artistic works throughout the world; whereas the protection of copyright and neighbouring rights should therefore be consolidated at national, Community and international level; Whereas, because of the level of protection they guarantee for literary and artistic works, rights of performers, producers of phonograms and broadcasting organizations, the Berne Convention for the Protection of Literary and Artistic works enshrined in the Paris Act of 24 July 1971 (Paris Act of the Berne Convention), and the International Convention for the Protection of Performers, Producers of Phonograms and Broadcasting Organizations (Rome Convention) of 26 October 1961 enjoy a wide and increasing international acceptance; 3

it is necessary that "the Member States of the Community, in so far as they have not already done so, undertake, subject to their constitutional provisions, to become by 1 January 1995

\footnotetext{
1 Published in JO L 167, 22.6.2001, p. 10-19.

${ }^{2}$ Council Resolution of 14 May 1992 on increased protection for copyright and neighbouring rights, published in J.O. C 138, 28.05.1992, p. 01.

3 http:/ / eur-lex.europa.eu/legal-

content/EN/TXT/?uri=uriserv:OJ.C_.1992.138.01.0001.01.ENG\&toc=OJ:C:1992:138:TOC
} 
parties to the Paris Act of the Berne Convention and the Rome Convention, and to introduce national legislation to ensure effective compliance therewith."4

Therefore, at EU level, in addition to international treaties that have been ratified by the $\mathrm{EU}$ as an international law entity, its internal regulations, which may be in the form of regulations, decisions or directives, apply. Following the study on the related legislation, it can be seen that the vast majority of the normative acts governing intellectual property, copyright and related rights in the EU are regulated under the directives. ${ }^{5}$ It implies that they must be transposed by the Member States into their national legislation.

Among the existing normative acts at both international and European level, the present study will only refer to those that address elements of copyright protection and related rights in the light of current issues arising from the existence and development of the information society.

\section{The European Union vision on the harmonization of copyright and related rights with other rights}

When it comes to harmonization, at least the following aspects need to be taken into account: the definition of the scope and terms, the identification of the problems subject to harmonization, the possible exceptions and the basic legislative framework and the extended one by way of connection.

\section{Defining the problem}

When defining the information society under EU law, this term is shown "describes a society where a significant degree of activity focuses on the creation, distribution, use and reuse of information" which "offer opportunities like teleworking, ehealth and elearning to name but a few" but which also has negative effects through "new forms of crime, such as cyber crime, as well as data protection and intellectual property violations." 6

Since the meeting of the 1994 European Council in Corfu, when discussing the need to develop and implement legislation to help develop an information society, it has been shown that unprecedented technological revolution in the area of information opens up vast possibilities for economic progress, employment and the quality of life, while simultaneously representing a major challenge, but that it requires to creating a clear and stable regulatory framework (notably as regards access to markets, compatibility between networks, intellectual property rights, data protection and copyright) and setting an example in areas which come under their aegis. ${ }^{7}$

\footnotetext{
${ }^{4}$ Resolution of 14 may 1992, point 1.

${ }^{5}$ Directive 83 of 1993 on the coordination of certain rules concerning copyright and rights related to copyright applicable to satellite broadcasting and cable retransmission; Directive 9 of 1996 on the legal protection of databases; Directive 84 of 1998 on the legal protection of services based on, or consisting of, conditional access; Directive 84 of 2001 on the resale right for the benefit of the author of an original work of art; Directive 48 of 2004 on the enforcement of intellectual property rights; Directive 116 of 2006 on the Term of Protection of Copyright and Certain Related Rights; Directive 115 of 2006 on rental right and lending right and on certain rights related to copyright in the field of intellectual property; Directive 24 of 2009 on the legal protection of computer programs; Directive 28 of 2012 on certain permitted uses of orphan works; Directive 26 of 2014 on collective management of copyright and related rights and multi-territorial licensing of rights in musical works for online use in the internal market.

${ }^{6}$ http://eur-lex.europa.eu/summary/glossary/information_society.html.

${ }^{7}$ European Council at Corfu 24 - 25 June 1994, Presidency Conclusions, White Paper, http://www2.consilium.europa.eu/media/21207/corfu-european-council.pdf., p.5.
} 
On the international level, in 1996, the World Intellectual Property Organization (WIPO) by The Copyright Treaty establishes new international regulations and clarifies the interpretation of certain existing regulations in order to find appropriate solutions to the issues raised by developments in the economic, social, cultural and technical, having regard to the evolution and convergence of information and communication techniques which have a considerable impact on the creation and use of literary and artistic works. ${ }^{8}$ This Treaty seeks to maintain a balance between the rights of authors and the interests of the general public, particularly in the fields of education, research and access to information, as is apparent from the Berne Convention. The WIPO Copyright Treaty was signed by the EU on 20 December 1996, ratified on 14 December 2009 and entered into force on 14 March $2010 .{ }^{9}$

The transposition of the Treaty provisions into EU law was made through the Directive 29 from 2001 on the harmonization of certain aspects of copyright and related rights in the information society. The preamble to this directive states that the proposed harmonization will help to implement the four freedoms of the internal market and refers to respect for fundamental principles of law, in particular property, including intellectual property, freedom of expression and public interest. ${ }^{10}$ Referring to the information society, the preamble also states that technological development has multiplied and diversified the creativity, production and exploitation vectors. Even if new concepts for the protection of intellectual property are not needed, current legislation on copyright and related rights needs to be adapted and supplemented to adequately reflect economic realities such as new forms of exploitation. ${ }^{11}$

Another effect of Community harmonization through the implementation of the Directive is that of avoiding significant differences in protection through decisions resulting from legislative action promoted at Member State level with possible negative effects on the free movement of services and products incorporating or based on ownership intellectual.

The impact of such legislative differences and legal uncertainty is becoming more important with the evolution of the information society, which has already led to the intensification of the cross-border exploitation of intellectual property.

\section{Limitations and exceptions}

Rights are legally aware of the existence of corresponding obligations, i.e. any right belonging to a person corresponds to an obligation belonging to another person. In the exercise of copyright and related rights, the right-holder is entitled to demand or oblige others to fully respect the legal content of these rights.

Social reality and the complexity of rights sometimes lead to limitations or exceptions to the exercise, the recognition of rights.

Neither copyright nor related rights have escaped interference with the existence and exercise of other rights. The protection of copyright and related rights comes into contact with:

- Promoting education and culture, leading to exceptions or limitations of public interest for education and education purposes. However, these must not be achieved by

\footnotetext{
8 WIPO Copyright Treaty (WCT), adopted in Geneva on December 20, 1996, Preamble, p.1, http://www.wipo.int/wipolex/en/treaties/text.jsp?file_id=295157.

${ }^{9} \mathrm{http}: / /$ www.wipo.int/treaties/en/remarks.jsp?cnty_id=3P.

${ }^{10}$ Directive 29 on 2001, preambul, pc.(3), http:/ / eur-lex.europa.eu/legalcontent/RO/TXT/?qid=1511787691474\&uri=CELEX:02001L0029-20010622.

${ }^{11}$ Idem, pc.(5).
} 
sacrificing strict protection of rights or by tolerance of the illegal forms of distribution of counterfeit or pirated works.

- Public communication acts, understood in a broad sense. The Directive states in paragraph 23 of the preamble that acts of public communication mean any communication to a public not present at the place of origin of the communication. This right includes exclusively any transmission or retransmission of any kind of work to the public, whether cable or cable, including broadcasting.

- The rights and interests of users of protected objects analyzed in the light of the new electronic environment and the increase in cross-border exploitation of works. In this situation, it is even more evident the importance of legislative harmonization which otherwise would lead, through national exceptions, to direct negative effects on the functioning of the internal market in the field of copyright and related rights.

- Scientific research, for the benefit of public institutions, such as libraries and archives.

- Use for the benefit of persons with disabilities, public safety or administrative or judicial proceedings.

As a conclusion, these exceptions and limitations to the exercise of copyright and related rights concern the reproduction right and the right of public communication.

\section{Legislative framework combined}

Starting from the provisions of Directive 29 of 2001 on the harmonization of certain aspects of copyright and related rights in the information society, we find that they are in line with the provisions of:

- Directive 9 from 1996 on the legal protection of databases ${ }^{12}$ which is referred to when 'technical measures' are taken into account for the protection of copyright and related rights and sui generis right as governed by Directive 9 of 1996;

- Directive 31 of 2000 on certain legal aspects of information society services, in particular electronic commerce in the internal market. ${ }^{13}$ This directive, which regulates information society services, envisages a wide range of online business activities, including book sales.

- Directive 115 of 2006 on rental and lending right and certain rights related to copyright in the field of intellectual property ${ }^{14}$ which repealed Directive 100 of 1992 . In this situation, a distinction is made between the distribution right provided for by Directive 29 of 2001 and the rental or loan rights provided for in Directive 115 of 2006. Harmonization of provisions also refers to the establishment of exceptions or limitations for the benefit of certain non-profit institutions, such as public libraries and equivalent institutions, as well as archives without the right to reproduce.

- Directive 116 of 2006 on the term of protection of copyright and related rights ${ }^{15}$ and repealing Directive 93/98 / EEC

- Directive 24 of 2009 on the legal protection of computer programs ${ }^{16}$, which repealed Directive 250 of 1991. The link with this normative act is given by the possible existence of the technical measures used in connection with the computer programs and the exceptions provided by this directive.

\footnotetext{
12 Published in JO L 77, 27.3.1996, p. 20-28.

${ }^{13}$ Published in JO L $178,17.7 .2000$, p. 1-16

${ }^{14}$ Published in JO L 376, 27.12.2006, p. 28-35

${ }_{15}$ Published in JO L 372, 27.12.2006, p. 12-18

16 Published in JO L 111, 5.5.2009, p. 16-22
} 
Aspects on the Harmonization of Copyright...

By establishing these legal links, the principles and norms specific to the placement of copyright protection and related rights in the context of the information society are developed.

\section{Aspects regarding difficulties of unitary interpretation of the provisions}

If the provisions on the regulatory scope of Directive 29 of 2001 are clear, the exceptions and limitations provided for therein are those which raise questions as to their interpretation in concrete situations.

Considering that the over 20 exceptions and limitations provided for in Article 5 of the Directive cover a wide range of situations regarding: the protection of the reproduction right provided for in Article 2; the right to publicize works and to make available to the public other protected objects provided for in Article 3; and the exclusive right of the author of distribution provided for in Article 4, differences of practical interpretation were expected to occur.

Including the interpretation of the exceptions should be made by corroborating several normative acts, such as the above.

In this regard, in Case Productores de Música de España (Promusicae)/Telefónica de España SAU in which a reference for a preliminary ruling was made, it is stated that

Community law requires that, when transposing those directives, the Member States take care to rely on an interpretation of them which allows a fair balance to be struck between the various fundamental rights protected by the Community legal order. Further, when implementing the measures transposing those directives, the authorities and courts of the Member States must not only interpret their national law in a manner consistent with those directives but also make sure that they do not rely on an interpretation of them which would be in conflict with those fundamental rights or with the other general principles of Community law, such as the principle of proportionality. ${ }^{17}$

By judgment of the Court (Fourth Chamber) of 16 July 2009 in Infopaq International A / $\mathrm{S} \mathrm{v}$ Danske Dagblades Forening, a practical aspect of the exception concerning the transitional nature of the act of reproduction is settled. In the present case, starting from the idea that the parts of a work are protected by copyright if they contain some of the elements which are the expression of the author's own intellectual creation, it is established that:

The act of printing out an extract of 11 words, during a data capture process consisting in scanning of newspaper articles followed by conversion into text file, electronic processing of the reproduction, storage of part of that reproduction and printing out, does not fulfil the condition of being transient in nature as required by Article 5(1) of Directive 2001/29 on the harmonisation of certain aspects of copyright and related rights in the information society and, therefore, that process cannot be carried out without the consent of the relevant right-holders. ${ }^{18}$

Another exception brought before the Court concerns the private copy. In this respect, a distinction shall be made between the copy made by equipment, apparatus and digital

\footnotetext{
${ }^{17}$ Case C-275/06, studied at http:/ / eur-lex.europa.eu/legalcontent/RO/SUM/?uri=CELEX:62006CJ0275\&qid=1511811389802.

${ }_{18}$ Case C-5/08, pc. 63-73, studied at http://eur-lex.europa.eu/legalcontent/RO/TXT/?qid=1511811389802\&uri=CELEX:62008CJ0005.
} 
reproduction media, made available, in law or in fact, to private users and copy made by equipment, apparatus and digital reproduction media that are not made available to private users and which are clearly intended for use other than the making of copies for personal use. In the first situation, as a result of applying the exception, the use of a fee paid by those who hold such equipment for fair compensation of copyright and related rights is presumed to be the use of all the functions performed by such equipment, including the reproduction function. ${ }^{19}$

More recently, one case ${ }^{20}$ calls into question the protection of copyright and related rights, expressed in the form of reproductive rights and public communication, in the case of 'unavailable' books which do not or are no longer the subject of publication. As is also apparent from paragraphs 30 and 31 of the judgment, the harmonization made by Directive 29 of 2001 cannot be limited to the benefit of the rights guaranteed but must also be taken into account when exercising the rights. In particular, bring into question the way of applying the preventive character of the provisions of art. (2) and (3) of the Directive when the author's prior consent for reproduction and publicity acts must be obtained. Since the law it does not specify the way or the form in which this consent must be given, ie explicitly or implicitly, verbally or in writing, in order to give meaning to the law and not without content the principle of the author's prior consent, it must be understood that even the implicit consensus may be accepted, with the condition to the existence of effective prior information. Otherwise, any act of reproduction or public communication, even if it is done on the basis of a national normative act based on the provisions of art. 5 of Directive 29 of 2001 do not comply with the principles governing this legal act. The judgment states in paragraphs 43 to 45 and 52 that

a mere lack of opposition on their part cannot be regarded as the expression of their implicit consent to that use. This is all the more true considering that such legislation is aimed at books which, while having been published and commercially distributed in the past, are so no longer. That particular context precludes the conclusion that it can reasonably be presumed that, without opposition on their part, every author of these 'forgotten' books is, however, in favour of the 'resurrection' of their works, in view of their commercial use in a digital format. Admittedly, Directive 2001/29 does not preclude national legislation, such as that at issue in the main proceedings, from pursuing an objective such as the digital exploitation of out-of-print books in the cultural interest of consumers and of society as a whole. However, the pursuit of that objective and of that interest cannot justify a derogation not provided for by the EU legislature to the protection that authors are ensured by that directive

As some authors state, there is a lack of information on the level of conceptualization of informed consent in European and East European countries. ${ }^{21}$

\footnotetext{
${ }^{19}$ Judgment of the Court (Third Chamber) of 21 October 2010. Padawan SL against Sociedad General de Autores y Editores de España (SGAE). Case C-467/08, studied on http://eur-lex.europa.eu/legalcontent/RO/TXT/?qid=1511811389802\&uri=CELEX:62008CJ0467.

${ }^{20}$ Cauza C-301/15, Marc Soulier și Sara Doke împotriva Premier ministre și Ministre de la Culture et de la Communication, http://eur-lex.europa.eu/legalcontent/RO/TXT/?qid=1511817016817\&uri=CELEX:62015CJ0301.

${ }^{21}$ Lorena Dima, Angela Repanovici, Daniel Purcaru et al., "Informed Consent and E-Communication in Medicine," Revista Romana De Bioetica 12 (2) (2014): 37-46.
} 


\section{Conclusions}

The protection of copyright and related rights, even though they benefit from regulations that have, at least in the field of international law, a considerable length of time, are constantly changing.

These changes are due either to the effect of the evolution of the technique on these modes of expression, or to the exercise of these rights, or to the refining of the regulatory way, by the existence of more and more connections with other domains and other fundamental rights.

It remains to be decided how the national specificity, allowed both by the transposition rules of a directive and by the provisions of Directive 29 of 2001, must or may take into account the fundamental rights enshrined in the Charter of Fundamental Rights of the European Union in determining the scope of the exceptions. The interference of rights and interests in this field is and will be topical, being solved in principle on the field of the courts of law.

The issues raised and presented in this study only show the top of the iceberg of issues related to the protection of copyright and related rights. This is because only a very small part of the problems of interpretation and application of the specific legislation raised by the holders of these rights before national courts come to the Court.

Better knowledge of copyright-related legislation and related rights by institutions involved in acts involving the existence of these rights, combined with dissemination to the general public, may be a way of preventing the various forms of attainment of these rights.

\section{References}

Dima, Lorena, Angela Repanovici, Daniel Purcaru et al. "Informed Consent and ECommunication in Medicine.” Revista Română de Bioetică 12 (2) (2014): 37-46.

\section{International and European Union reglementation}

WIPO Copyright Treaty (WCT), adopted in Geneva on December 20, 1996, http://www.wipo.int/wipolex/en/treaties/text.jsp?file_id=295157 (accessed September 29, 2017).

Council Resolution of 14 May 1992 on increased protection for copyright and neighbouring rights, published in J.O. C 138, 28.05.1992, p. 01, http:// eur-lex.europa.eu/legalcontent/EN/TXT/?uri=uriserv:OJ.C_.1992.138.01.0001.01.ENG\&toc=OJ:C:1992:138:T OC, (accessed September 29, 2017).

Directive 83 of 1993 on the coordination of certain rules concerning copyright and rights related to copyright applicable to satellite broadcasting and cable retransmission; http:/ / eur-lex.europa.eu/legalcontent/RO/TXT/?qid=1512251288974\&uri=CELEX:31993L0083 (accessed October 7, 2017).

Directive 9 of 1996 on the legal protection of databases; Published in JO L 77, 27.3.1996, p. 20-28, http:/ / eur-lex.europa.eu/legalcontent/RO/TXT/?qid=1512251438967\&uri=CELEX:31996L0009 (accessed October 6, 2017).

Directive 84 of 1998 on the legal protection of services based on, or consisting of, conditional access; http://eur-lex.europa.eu/legalcontent/RO/TXT/?qid=1512251513127\&uri=CELEX:31998L0084 (accessed October 7, 2017). 
Directive 29 of 2001 on the harmonisation of certain aspects of copyright and related rights in the information society Published in JO L 167, 22.6.2001, p. 10-19, http:/ / eurlex.europa.eu/legal-content/RO/TXT/?qid=1511787691474\&uri=CELEX:02001L002920010622 (accessed September 30, 2017).

Directive 31 din 2000 on certain legal aspects of information society services, in particular electronic commerce, in the Internal Market, Published in JO L 178, 17.7.2000, p. 1 16 http://eur-lex.europa.eu/legalcontent/RO/TXT/?qid=1512251756365\&uri=CELEX:32000L0031 (accessed October 8, 2017).

Directive 84 of 2001 on the resale right for the benefit of the author of an original work of art; http:/ / eur-lex.europa.eu/legalcontent/RO/TXT/?qid=1512251988603\&uri=CELEX:32001L0084 (accessed October 8, 2017).

Directive 48 of 2004 on the enforcement of intellectual property rights; Published in JO L 157, 30.4.2004, p. 45-86 http:/ / eur-lex.europa.eu/legal-

content/RO/TXT/?qid=1512252065009\&uri=CELEX:32004L0048 (accessed September 29, 2017).

Directive 115 of 2006 on rental right and lending right and on certain rights related to copyright in the field of intellectual property; Published in JO L 376, 27.12.2006, p. 28-35 http://eur-lex.europa.eu/legal-

content/RO/TXT/?qid=1512252493990\&uri=CELEX:32006L0115 (accessed September 30, 2017).

Directive 116 of 2006 on the Term of Protection of Copyright and Certain Related Rights; Published in JO L 372, 27.12.2006, p. 12-18 http://eur-lex.europa.eu/legalcontent $/$ RO/TXT/?qid=1512252631741\&uri=CELEX:32006L0116 (accessed September 30, 2017).

Directive 24 of 2009 on the legal protection of computer programs; Published in JO L 111, 5.5.2009, p. 16-22, http://eur-lex.europa.eu/legalcontent/RO/TXT/?qid=1512253135931\&uri=CELEX:32009L0024 (accessed October 12, 2017).

Directive 28 of 2012 on certain permitted uses of orphan works; Published in JO L 299, 27.10.2012, p. 5-12, http:// eur-lex.europa.eu/legalcontent/RO/TXT/?qid=1512253195898\&uri=CELEX:32012L0028 (accessed October 10, 2017).

Directive 26 of 2014 on collective management of copyright and related rights and multiterritorial licensing of rights in musical works for online use in the internal market, Published in JO L 84, 20.3.2014, p. 72-98, http:/ / eur-lex.europa.eu/legalcontent/RO/TXT/?qid=1512253297852\&uri=CELEX:32014L0026 (accessed October 12, 2017).

Presidency Conclusions, White Paper, European Council at Corfu 24 - 25 June 1994, , http://www2.consilium.europa.eu/media/21207/corfu-european-council.pdf., p.5 (accessed September 29, 2017).

\section{Case studies}

Case C-275/06, Productores de Música de España (Promusicae)/Telefónica de España SAU, studied at http:/ / eur-lex.europa.eu/legalcontent/RO/SUM/?uri=CELEX:62006CJ0275\&qid=1511811389802 (accessed October 13, 2017). 
Aspects on the Harmonization of Copyright...

Case C-5/08, Infopaq International A/S v. Danske Dagblades Forening, studied at http://eur-lex.europa.eu/legal-

content/RO/TXT/?qid=1511811389802\&uri=CELEX:62008CJ0005 (accessed October 14, 2017).

Case C-467/08, Padawan SL against Sociedad General de Autores y Editores de España (SGAE)., studied on http://eur-lex.europa.eu/legalcontent/RO/TXT/?qid=1511811389802\&uri=CELEX:62008CJ0467 (accessed October 14, 2017).

Cauza C-301/15, Marc Soulier and Sara Doke v. Premier ministre and Ministre de la Culture et de la Communication, http:/ / eur-lex.europa.eu/legalcontent/RO/TXT/?qid=1511817016817\&uri=CELEX:62015CJ0301 (accessed October 13, 2017). 